\title{
Political Promises in the Perspectives of Islam and Its Implementation in Development Policy
}

\author{
M. Sidi Ritaudin \\ Departement of Islamic Political Though. Faculty of Ushuluddin \\ Islamic State University of Raden Intan Lampung
}

Doi: $10.2478 / \mathrm{mjss}-2018-0076$

\begin{abstract}
After the election, the mayor and vice mayor of Bandar Lampung should prepare strategic policies through medium-term development plan based on the political promises during the campaign period. This article discussed the issue on how the implementation of political promises of the mayor of Bandar Lampung. This research is a kind of media research, which is composed of the political promises recorded in the mass media. The analysis used in this research was a descriptive method and content analysis. The results showed that the political promises of Herman HN were generally carried out in accordance with his commitments. Although, there are were still many shortcomings, such as inaction and uneven development in Bandar Lampung city due to budget constraints and lack of coordination within the government itself as well as with representatives in Parliament. However, the people of Bandar Lampung are generally believed that their political promises are debt, which should be implemented during the period of his reign. Promises will be demanded by the people and all of which were recorded in the print media, in the Lampung Post, Tribune Lampung, and Radar Lampung.
\end{abstract}

Keywords: political promise, mayoral election, political campaigns, Islamic perspective, development policy

\section{Introduction}

Stereotypically, it is of a general opinion that politics is a dirty arena since the players often make promises. Promises are made in order to obtain power and they will ultimately be forgotten after the politician who made them obtain power. When talking about improving the quality of a democratic civilization, one of the subjects that should get serious attention is how to treat the promises in the campaign. Since religious people agree that the political promises during the campaign are "debts" that must be paid by the political policy, it is a weak hadith, thus, it should not be ascribed to Rasûlullâh Shallallahu 'alaihi wa sallam and should not be used as an argument to determine that the position of promise in Islam is the same as debt. Let the Quran and the sahih hadith from Rasûlullâh as the guarantee and argumentation on the obligation to fulfill the promise and prohibition to deny it.

Politicians, perhaps, do not intend to deceive the public when giving promises in their campaign. There have been many political promises among the competitors to win the election. On the other hand, people do not tend to record the political promises so that the politicians and the public quickly forget the promises. As a diplomacy political promises are a power of politic. Berridge (2012, p.1) said that political activity must besupported by great ability, insofar that diplomacy has a fungtion as relation of managing political interaction.(Barston, 1997, p.8). In the mayoral election of Bandar Lampung, what has been done by the competitors was an effort to get sympathy from the people as diplomacy. In the present political atmosphere, it was not easy to achieve the people's sympathy since people demand the candidate to campaign more realistic promises which refer to 
the actual fact.

The comeback of Herman $\mathrm{HN}$ as one of the candidates for Mayor of Bandar Lampung is phenomenal since the people have been united and proclaimed to elect the incumbent candidate, based on "many" achievements. Some of them are the infrastructure development in several fields, such as, the construction of three flyovers, a government-funded school, and free medical services for the poor people. Therefore, instead of using his success in the previous term, He should not give many promises, but rather give more information and thoughts suited to the current facts. It is important to note that apolitical promise is not a tool to deceive people for getting sympathy on the day of election, what is more essential is on how far a candidate is able to give political education-based advices. As for theoritical politics, political promises can not be separated from the body politic as based on community, justice and leadership.(Ayubi, 1991, p.7), because the general assumption is that political power and bureaucratic authority are held by state officials, (Robinson, 1993), which makes people less concerned with elections until candidates make political promises on election day. This research is supposed to have affiliation with Muslim-majority countries such as Malaysia, Berunai Darussalam, Turkey and others who in general elections often make political promises

\section{Research Methodology}

Research conducted by type can be categorized as field research. The data obtained in the field are texts of political promises candidate incumbent in print media circulating in Bandar Lampung, namely, Lampung Post, Tribune Lampung, and Radar Lampung, and other media that publishes weekly as a complement. Then the data were confirmed by interviewing the heads of political parties that supported the nomination of the candidates in election. This study comes from an Islamic perspective, which will be done by reviewing the media discourse about the promises of a political candidate, which is a correlational ex-post facto research, because it does not provide treatment, but rather reveals the facts that occur naturally and that happens in public political response in accordance with the insights and knowledge that they have. It is said to be correlational because it will investigate the influence between research variables.

Researchers use grounded research, i.e., research that focuses on the qualitative approach on the basis of data obtained from the analysis of media discourse in Bandar Lampung. The analytical technique used in this research is the technique of text analysis, because the emphasis of research using the existing texts in print media. The research of this media text used the descriptive qualitative approach and the text research technique, that is Framing Pan and Kosicki analysis, to know the construction and frame of news in media, especially the news about political promises.

\section{The Issues of Political Promises in Reality}

"It is better to reject politely than give many promises". (Sayyidina 'Ali ibn Abi Talib RA). That quote became the political adage what was often forgotten. Politicians often prioritize political ambition rather than enforcing the morality and political wisdom due to the influence of Thomas Hobes's idea. Therefore, it is no wonder if the politics is often labeled as a dirty arena because the actors/players often give many promises to take power, but forget them after obtaining power. As Hegel and Thomas Hobes, Max Weber considers that the state is the only institution that has the freedom to perpetrate violence against its citizens (Gerth,1962, p.78). So, one of the cases that need serious attention is how to treat promises in the campaign.

In 2015, three pairs of candidates competing in the election of mayor and vice mayor of Bandar Lampung, gave many promises which would be implemented if they won the election. For example, they signed a lot of political contracts. It is a form of obedience to fulfill their promises. As the winner of the election, they had more difficult burden due to their political promises. Their promised to continue the programs they had launched in the previous period, such as, constructing flyovers, repairing on damaged roads, free health and education facilities and infrastructures, and reducing poverty in Bandar Lampung City. 
Another promise remembered by the people is free schooling and medical services, both mayor and vice mayor committed to realize the welfare of the people through an environmental development program and increasing the employment opportunities to reduce unemployment. Indeed, these implementation of governance systems and mechanisms contain the practices of fulfillment of the promises, in the form of development programs. However, the realization these promises cannot simply be implemented and reached because of a system of checks and balances among government institutions, especially between the executives and the Regional House of Representatives. Its mean, that the government is obliged to submit to the authority of the state. (Asad, 1961, p. 64--81).

It is expected to have a system of "demand- and- report mechanisms" toward campaign promises. For example, people can periodically demand the fulfillment of promises through a forum in the Regional People's Representative Assembly or directly with the mayor. Then he or the vicemayor can also periodically report the realization of the promises in the forum meeting with the people in every village and sub-district, as a form of enforcing transparency in a democracy. At the time of the campaign, the candidates diligently visite the villages to have close conversations with the people. Then, it is very possible to improve intensively after they served as a head of Bandar Lampung City. To carry out an appointment is the moral law of human nature, which is both good and evil (Farrell, 1931, p.75--85). It is a realization on responsible political promise. There must be no presumption that it is normal to forget political promises such that the candidates can lie massively in their campaign without feeling guilty.

The perspective of Islam on giving promises but with no implementation, is alleged in the Quran in the following verses: O you who have believed, why do you say what you do not do? Great is hatred in the sight of Allah that you say what you do not do. (QS. As-Shaf: 2-3). According to the interpretation by Ibn Katsir, this verse is a kind of Allah's disavowal to those who are not able to do what they say. Therefore, there are some salaf ulema that make this verse a proposition that fulfilling a promise is an absolute obligation, that either the promise results in punishment or not for those who made it. They also argue that it is based on the hadith recorded in ash-Shahiihain, in which Rasulullah SAW said, "There are three characteristics of a hypocrite; when he speaks he lies, when he gives a promise he breaks it, and when he is trusted he is treacherous". This is called by Machiavelli as the common good, i.e, for the sake of the homeland, then every way can be taken.(Walker, 1950. p. I, 9).

By paying attention to the message in the verse of the Quran above, it is not allowed to break political promises that have been presented in public during the campaign. It is a promise, and the promise is a debt that must be paid for by deeds. If the mayoral candidate had promised to improve the lives of the people through free education and medical services programs, then when he captures power, his main task is to develop the programs that support towards the fulfillment of his political promises. The freedom of society to express their aspirations, this is what is called democracy. In Indonesia it is known as a form of democracy that most closely approaches the community in the implementation, (Lipset, 1960, p.97). Ethically, 'neither the mayor nor the vicemayor candidate and their campaign team and supporting parties should not be giving many promises. The fact shows that people's interest on a candidate, generally, will be determined by his personal characteristics and track records, not by false promises. It all depends on the candidate's goal as the key. (Brecht, 1959, p.117--118).

Political promises commonly occurred among the leader candidates to their cronies and campaign teams, as well as to the people as the constituent. Although the hadith on "the promise is a debt" is weak/dhaif, it is believed that the promise has to be paid. (Baqi, tt, p. 921--923). It is because the candidates gave many promises to the constituents at their campaigns and the constituents voted them in supports to the political promises, so that the elected candidate must fulfill his promises to reciprocate. As the national leader, Herman HN has been described as the individual who "always sets the tone and articulates the main thematic qualities of what might be called the official ideology" (Bill, 1974, p.228).

The problems arise in the campaign when a candidate stars projecting excessive self-imaging, and overconfidence. Surah An-Nisa' verse 49 states that: Haven't you seen those who claim themselves to be pure? Rather, Allah purifies whom He wills, and injustice is not done to them. In 
the context of a campaign that prioritizes imaging, it can be considered part of the category of vanity (ujub), arrogance, and self-conceit. Although self-imaging is allowed in another side, it is considered to be less-worthy if one projects self-imaging without considering the interest of the nation and country especially the impoverished (dhu'afa') people.

The strictest prohibition in Islam in the context of a campaign is the prohibition on vote-buying. It is a kind of great sins and is considered a crime. Vote-buying in election has been known by some communities, it is not strange to them anymore, and some of them have witnessed it directly. Some regions have certain ways, forms, techniques, and patterns of vote-buying many people understand. Each party has a different level of committing this crime. Each candidate commits this based on his own potential and capabilities. So as with the voters, they have different values and prices for their votes. Some voters are valued as luxury cars go and some are valued only based on basic commodities packages, which are just enough to momentarily fulfill their hunger.

\section{The Implementation of Political Promises in Development Policy}

The local government of Bandar Lampung City successfully conducted its political reciprocation by implementing political promises. The development of infrastructure was successful through the building of three flyovers, and widening and reparing roads, the same can be said about the education and health sectors. The effect of ethical politics played a very important role in the development and expansion of education, there were some changes for the better future of the people and welfare, such as the implementation of environmental-development-based schools, and free medical services, enabling a market economy, independent communication media and so forth. (Beetham, 1995, p.158). Apart from the "money politic", black campaign, and various political violence commonly known as the practice of political pathology, the disunited society sees that the ethical politics of Herman HN had successfully hypnotized the constituents of Bandar Lampung, so that he succeeded to earn $85 \%$ votes.

On the other hand, there is the spectrum of religion, which asserts that "Promise is a Debt", as this hadith cannot be ignored since keeping a promise is a proof that a person is great. He who does not implement mandate has no religion, and he who does not fulfill his promise has no religion, that it is not easy to be a trustworthy leader; therefore, a leader must be strong and firm in the face of political turbulence. So, although one you will be poor due to paying one's debt, it is better than diying while having the debt unpaid.

Religion is one of political appeal, because with the religion of society will be more confident in political promises, the religion-related issue was made as an approach to gain votes, such as promoting the religious studies and approaching the religious leaders. Generally, society has been antipathetic, pessimistic, indifferent, and ignorant. It is due to the assumption that whoever comes from any political party could not respond and represent their desires and expectations in Parliament or even to the executives. Therefore, as in the previous election, they used religion in their campaign.

The independence of the party is only limited to platforms and budget. However, the elites of the parties prefer to have a coalition and being closer to the ruling party. There is no courage to be the opposition, always having the horse-trading politics phenomenon, transactional politics, even proud of power. The phenomenon of political pathology, such as corruption, collusion, and nepotism, has built a negative perception within the people that resulted in apathy. This perception had an impact on the choices made by students today, where they could not be proud of entering the politics after finishing their studies. Even as some of them participate in politics, it is not based on their conscience, but merely for a pragmatic view in which they want to get rich instantly. By having a power, either the executive or the legislative, there is a great opportunity to enrich themselves, since the power can be abused, as said by the experts that power tends to corrupt.

That singular perception is likely to worsen politics. The positive response among the youth, on political parties, especially the Islamic parties, will determine the nation's future. It can be assumed that the more positive the public perception is, especially among the youth within the Islamic parties, the greater is the political participation in the life of the nation. In the end, the Islamic parties will have the majority votes in parliament. Thus, the hopes to implement religious 
values in the country will have greater opportunity. Hopefully, the concept of baldatun thayyibatun wa rabbun khafur can be realized in this country.

However, all political parties were still strongly co-opted and infiltrated by the government, because they were the members of a big coalition of the ruling party, which was still showing superiority and hegemony, and even were included in the program of "depoliticization of Islam" that the treatment given by the country to the Muslim community is similar to the treatment of a ringworm-infected cat. Thus, it is very doubtful that Islam will reach its goal in this political year by seing the actions of the existing Islamic parties.

\section{Political Reciprocation}

The main highlight in this sub-discussion is the reciprocation, which means the distribution of power in terms of politics, the distribution of the bribe after obtaining victory. How does Islam react to it? Indeed, Islam does recognize that the elections result in several principal benefits. One of them is to prevent injustice and tyranny. However, it is possible that new injustice and tyranny will occurr in newly acquired power. If so, the evil is more dominant than the benefit. The elections contribute to eliminate injustice, to protect the people from tyranny and oppression of tyrants, to eliminate the misuse of public money, to preserve safety, and to preserve people's dignity. However, power is still susceptible to being abused. Although power is actually the source of law, the law can not limit it, because Jean Baudin says that God's power can not be restricted by the rule of law that exists because He himself is the source of the law. (Sabine, 1973, p.377), Meaning that man-made law must be sourced from the law that has been established by God.

Islam remains consistent in forbidding political reciprocation within the framework of political pathology. It is a form of political crimes wrapped in terms of reciprocation. Perhaps, the good deed is still understandable, but the evil deed such as political agitation, black campaign, self-imaging and immeasurable false promises, are considered crimes. It is such a high-level political conspiracy conducted by those whose want for power justifies all means. Election is a major problem related to public interest because a democratic government system makes the election a measure of the legitimacy of a government. Even countries that never held general elections, previously, have now began to enforce general elections, though in a few lines of their administration. This fact shows that the problem of elections is an important problem, and the answer is needed by the public. And, Fortunately, many scholars have discussed this problem. Then, as a Muslim, it is easy for one to refer one's statement/answer, as a practice of the sayings of God in the Quran: "So ask the people of the message if you do not know". (Annahl: 43)

\section{Islamic Law on Fulfilling Promise}

In conceptual theory, either through positive or religious law, the law of making promises is permissible (jaiz or also called as mubah). However, one is obliged to fulfill this promise. Being unable to fulfill his promise is haram and sinful. The sin is not only directed toward the people one has promised but also to Allah The Almighty. The bases of the obligation to fulfill the promise are among others: Allah says in the Quran, Surah An-Nahl, verse 91: "And fulfill the covenant of Allah when you have taken it, [O believers], and do not break oaths after their confirmation while you have made Allah, over you, a witness. Indeed, Allah knows what you do." Fulfilling a promise is a characteristic of a believer, as Allah says in Surah Al-Mukminun. One of the most important lessons is that they who keep their trust and promise. He says: "And they who are to their trusts and their promises attentive." Breaking a promise is Satan's act to deceive human, so that Satan will be happy once man is deceived. Allah says in Surah An-Nisa, verse 120: "Satan promises them and arouses desire in them. But Satan does not promise them except delusion."

From the description above, it is clear that it is obligatory to fulfill a promise. As in the Malay proverbs: Once trust is crushed, it would be hard to regain it. Nonetheless, as an equitable religion that always concerns on the situation and ability of the people, there are some situations which can be the exception of the law above, as follows: Being forced can be a reason that can allow a Muslim to cancel a promise he made, such as a Muslim who is restrained or prevented by which he 
cannot fulfill his promise, or a Muslim who is threatened with painful punishment. Rasulullah SAW said: "Verily Allah has pardoned for me my ummah: their mistakes, their forgetfulness, and that which they have been forced to do under duress."

Making promises to perform a forbidden/haram act or not to perform an obligatory act. Whoever promises someone that he will do something haram for him, or that he will not do something that is obligatory, it is not permissible for him to fulfil that promise. If something unforeseen happens to the one who made the promise, such as sickness, the death of a relative, or breakdown of his means of transportation, etc., by which the situation can be a right reason for him if he is not able to fulfill his promise, as Allah says: "Allah will burden us not with that which we have no ability to bear." (Al-Baqarah: 286).

In Islam, keeping promises, either big or small matter, and the promise is not related to committing immoral, bad, or accusing acts, but is a case that will be questioned by every Muslim. It is explained in a verse of the Quran, as Allah says: and fulfill [every] commitment. Indeed, the commitment is ever [that about which one will be] questioned. (QS. Al-Isra': 34) So, it is quite clear that as the servants of Allah, they should fulfill their promises at the time and history to which they promised.

\section{Conclusions}

Political reciprocation in the perspectives of Islam is actually a necessity. It has to be conducted even if it is obligatory, and a good deed makes a person become a leader with expectations of having visions and missions and is pro-society and is well-suited with the laws. There are some inhibitory and supporting factors in fulfilling their political promises, as follows: There is still a gap in the understanding of democracy between the politicians and public. The promise-demanding mechanism is still unclearly written in plateform. In general, people do not really concern and immediately forget the 5-year event of a campaign, so that the short-term memory of the public makes the governments do only the routine policies, which does not really develop and are not really as creative as their political promises.

\section{Referens}

Asad, Muhammad, (1961), The Principle of State and Government in Islam, Los Angeles, University of California Press.

Ayubi, Nazih (1991), Political Islam : Religion and Politics in the Arabs World, London : Roultedge

Barston R.P. (1997), Modern Diplomacy $2^{\text {nd }}$ edition, New York Addison Wesley Longman,

Baqi, Muhammad Fuad Abdul Al-Mu'jam Al Mufahras Lialfazhil Qur'anil Karim, Indonesia : Maktabah Dahlan, tt. Beetham, David \& Keven Bayle, (1995), Introducing Democray 80 Questions and Answers, Paris, UNISCO.

Bill, A. James, and Carl Leiden, (1974), The Middle East : Political and Power, Boston.

Brecht, Arnold (1959), Political Theory : The Foundations of Twentieth Century Political Thought, Princton University Press, Princton.

Farrell, W (1931) "Natural Foundations of the Political Philosophy of St. Thomas", Proceedings of the American Catholic Philosophical Association.

Geoff Berridge, (2012).Diplomacy: Theory and Practice $2^{\text {nd }}$ Edition, New Yoprk : Palgrave.

Gerth, H.H and C. Wright Mills (eds) (1962), From Max Weber : Essay in Sociology, New York : Oxford University Press.

Lipset, Seymour Martin, (1960). Political Man : The Social Bases of Politics, Garden City.

Ma'arif, Ahmad Syafi'i. (1985) Islam dan Masalah Kenegaraan Studi tentang Percaturan dalam Konstituante. Jakarta : Lembaga Penelitian Pendidikan dan Penerangan Ekonomi dan Sosial LP3ES.

Robinson, Richard,(1993) "Indonesia : Tensions in State and Regime" in Kevin Hewison, Ricard Robinson adn Garry Rodan, Southeast Asia in the 1990s Authoritarianism Democracy and Capitalism, St Leonards : Allan \& New York Outledge.

Sabine, George (1973), A History of Political Theory, Hindsale : Dryden Press.

Walker, LJ, (1950), The Discourses of Niccolo Machiavelly, London : Roulledge \& Kegan Paul. 